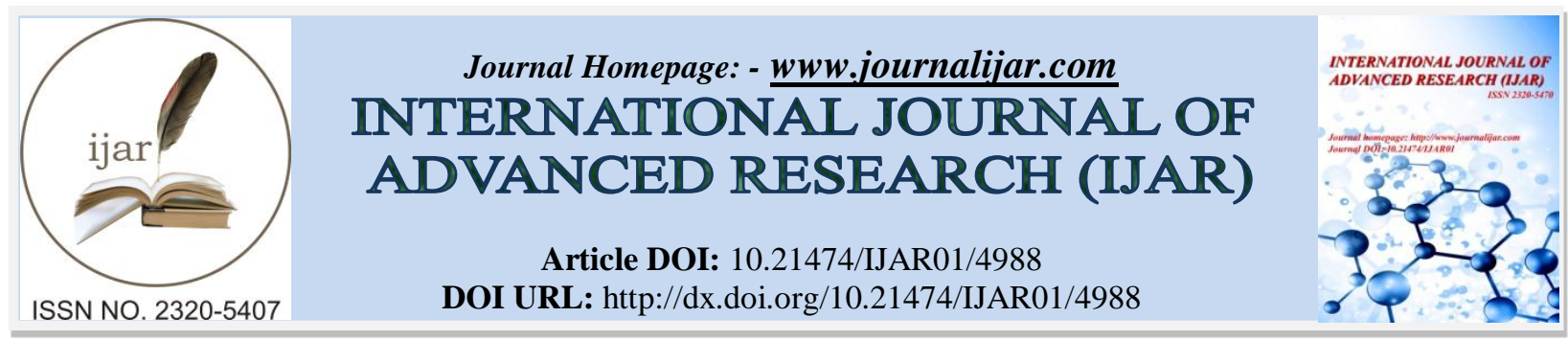

RESEARCH ARTICLE

\title{
QUALITATIVE ASSESSMENT OF THE FATTY ACID COMPOSITION OF EDIBLE SEAWEEDS FROM COASTAL AREAS OF MANILA BAY AND ROXAS CITY, PHILIPPINES.
}

Nancy Lazaro-Llanos and Sean Mikhail B. Dalawampu. Chemistry Department, De La Salle University-Manila, 2401 Taft Ave. Manila 1004, Philippines.

\section{Manuscript Info}

Manuscript History

Received: 27 May 2017

Final Accepted: 29 June 2017

Published: July 2017

Key words:-

Polyunsaturated fatty acids (PUFA), fatty acid methyl esters (FAME), Caulerpa, Hypnea, Gracilaria

\section{Abstract}

This study aimed to come up with a qualitative profile of the fatty acid composition of some of the most abundant seaweeds in the Philippines. Lipid extraction on the freeze-dried samples was done using a modified version of Bligh \& Dyer. The lipid extracts were derivatized into fatty acid methyl esters using based-catalyzed transesterification via methanolic potassium hydroxide solution and analyzed using gas chromatography mass spectrometry. Results revealed the presence of the following omega-3 fatty acids: linoleic, eicosatrienoic, and eicosapentaenoic. In addition polyunsaturated omega-6 and monosaunsaturated $\mathrm{C} 18$ fatty acids (oleic and eladic acid) have also been detected. This investigation has demonstrated the potential of edible seaweed as a significant source of omega-3 and other essential fatty acids.

Copy Right, IJAR, 2017,. All rights reserved.

\section{Introduction:-}

Seaweeds or marine macro-algae, have found a wide variety of applications. It is used as a constituent in pharmaceutical and personal care products; as fertilizers; as feed for livestock, as filtering agent in wastewater treatment; and as gelling agent, stabilizer, or emulsifier. Above all, the most popular use of seaweeds is as an ingredient in various exotic dishes like salads and soups. Seaweeds, widely accepted as health food, have been found to be rich in vitamins and minerals, proteins, fiber, phytochemicals, and have exhibited antibacterial and antioxidant properties (Benjama \& Masniyom 2011; Boonchu et al. 2011; Brownlee et al. 2012; Dawczynski et al. 2007; Fleurence 1999; Gressler et al. 2010; Ismail and Hong 2002; Lou et al. 2010; Matanjun et al. 2009; Mohammadi 2013; Norziah and Ching 2000; Ortiz et. al 2006; Polat \& Ozogul 2013; Ratana-arporn and Chirapart 2006; Shanab 2007; Seenivasan et al. 2012; Suresh et al. 2012). Studies have also shown that the relatively low lipid composition of seaweeds was found to be rich source of polyunsaturated fatty acids (PUFA) particularly that of omega-3 fatty acids which have been associated with the lowering of plasma cholesterol and triglycerides levels, reduced risk of developing cardiovascular diseases, improved immune system, etc. (Agree et al.1997; Bonaa et al. 1990; Connor 1994; Harris 1997; Ismail 2005; Horrocks 1999; Kinsella et al., 1990; Kris-Etherton et al., 2003; Oomen et. al. 2000; Schmidt 1997; Stone 1994). The American Heart Association recommended the ingestion of fish, preferably oil, at least twice a week (Kris-Etherton et al. 2003). In line with of the above, this study aimed to come up with a qualitative profile of the fatty acid composition of the most commonly consumed seaweeds in the Philippines.

Corresponding Author:- Nancy Lazaro-Llanos.

Address:- Chemistry Department, De La Salle University-Manila, 2401 Taft Ave. Manila 1004, Philippines. 


\section{Materials and Methods:-}

Seaweeds were gathered in June (Batch 1) and October (Batch 2). There were two areas of collection: Manila Bay in Luzon (Caulerpa racemosa Forskl. J.Ag. and Gracilaria tenuistipitata) and Roxas City in Central Philippines (Caulerpa racemosa Forskl. J.Ag.and Hynea nidulans Setchell). The samples were washed repeatedly with tap water and three times with distilled water, freeze-dried, grounded, and stored at $-20^{\circ} \mathrm{C}$.

A modified version of Bligh \& Dyer method (1959) was used to extract the lipids from the freeze-dried samples. Exactly 2 grams of each sample was successively soaked in the following solvents: methanol, 1:1 methanol:chloroform, and chloroform. After each addition, the mixture is stirred for two minutes and filtered. The filtrates were collected, pooled, and transferred to a separatory funnel. An equal volume of water was added and the mixture was allowed to stand for about three hours. The denser chloroform layer was collected, dried using anhydrous sodium sulphate, and concentrated under vacuum. The crude extract was re-dissolved in $2 \mathrm{~mL}$ hexane.

A $2.0 \mathrm{~mL}$ of $2 \mathrm{M}$ methanolic potassium hydroxide solution was added to each sample. The test tube containing the reaction mixture was covered by a rubber stopper and mixed for 1 minute using a vortex mixer. Afterwards, the upper hexane layer was collected using a glass syringe. Extracts were filtered into its respective glass vials using a Whattman filter, and then subjected to GC-MS analysis

GCMS model used was the Agilent Technologies 7890A GC System and 5977A MS System using two parameters. The first parameter was designed for optimizing peaks for EPA and DHA. For this method, total run time was set to 35 minutes with an injection volume of $1 \mu \mathrm{L}$. Initial temperature was set to $80^{\circ} \mathrm{C}$ with an increase of $10^{\circ} \mathrm{C}$ per minute until $300^{\circ} \mathrm{C}$ was reached. The second parameter was designed to optimize peaks relating to ALA. The total run time was set to 58 mins. with an injection volume $1 \mu \mathrm{L}$. Initial temperature was set to $80^{\circ} \mathrm{C}$ with an increase of $10^{\circ} \mathrm{C}$ per minute until $300^{\circ} \mathrm{C}$ was reached. Each run was done in duplicate.

\section{Identification of Seaweeds:-}

The seaweeds were identified and authenticated by the Botany Division of the Philippine National Museum.

\section{Results:-}

Table 1 shows the qualitative profile of the saturated fatty acid composition. Results demonstrate that C12-18 saturated fatty acids are present in all the samples regardless of the time and the place of collection. The difference is seen for $\mathrm{C} 20$ and above. The presence of C20 and above saturated fatty acids was noted in the green algae $C$. racemosa and very little up to none in the two red algae samples.

Table 1:- Qualitative Profile of the Saturated Fatty Acid Composition

\begin{tabular}{|c|c|c|c|c|c|c|c|c|c|}
\hline \multirow[t]{2}{*}{ Common Name } & \multirow[t]{2}{*}{ Notation } & \multicolumn{2}{|c|}{ G.tenuistiptata } & \multicolumn{2}{|c|}{$\begin{array}{l}\text { C. racemosa } \\
\text { (Luzon) }\end{array}$} & \multicolumn{2}{|c|}{ H. nidulans } & \multicolumn{2}{|c|}{$\begin{array}{l}\text { C. racemosa } \\
\text { (Central } \\
\text { Philippines) }\end{array}$} \\
\hline & & June & Oct & June & Oct & June & Oct & June & Oct \\
\hline Lauric acid & C 12:0 & + & + & + & + & + & + & + & + \\
\hline Tridecanoic acid & C 13:0 & + & + & + & + & + & + & + & + \\
\hline Myristic acid & C 14:0 & + & + & + & + & + & + & + & + \\
\hline Pentadecanoic acid & C 15:0 & + & + & + & + & + & + & + & + \\
\hline Palmitic acid & C 16:0 & + & + & + & + & + & + & + & + \\
\hline Heptadecanoic & C 17:0 & + & + & + & + & + & + & + & + \\
\hline Stearic acid & C 18:0 & + & + & + & + & + & + & + & + \\
\hline Arachidic acid & C 20:0 & & & & + & + & & & + \\
\hline Behenic acid & C 22:0 & & & + & + & & & + & + \\
\hline Tricosanoic acid & C 23:0 & & & & & & & + & \\
\hline Lignoceric acid & C 24:0 & & & + & + & & & + & + \\
\hline
\end{tabular}

The monounsaturated fatty acid (MUFA) composition is summarized in Table 2. Data shows the presence of both cis and trans $\mathrm{C} 18: 1 \Delta 9$, oleic and elaidic acid, respectively. 
Table 2:- Qualitative Profile of the Monounsaturated Fatty Acid (MUFA) Composition

\begin{tabular}{|c|c|c|c|c|c|c|c|c|c|}
\hline \multirow[t]{2}{*}{ Common Name } & \multirow[t]{2}{*}{ Notation } & \multicolumn{2}{|c|}{ G.tenuistiptata } & \multicolumn{2}{|c|}{$\begin{array}{l}\text { C. racemosa } \\
\text { (Luzon) }\end{array}$} & \multicolumn{2}{|c|}{ H. nidulans } & \multicolumn{2}{|c|}{$\begin{array}{l}\text { C. racemosa } \\
\text { (Central } \\
\text { Philippines) }\end{array}$} \\
\hline & & June & Oct & June & Oct & June & Oct & June & Oct \\
\hline Myristoleic acid & C $14: 1 \Delta 9$ & + & & + & + & + & + & & + \\
\hline Pentadecenoic acid & $\mathrm{C} 15: 1 \Delta 10$ & + & + & + & + & + & + & + & + \\
\hline Palmitoleic acid & C $16: 1 \Delta 9$ & + & + & + & + & + & + & + & + \\
\hline Heptadecenoic acid & $\mathrm{C} 17: 1 \Delta 10$ & + & + & + & + & + & + & + & + \\
\hline Oleic acid & C $18: 1 \Delta 9$ (cis) & + & + & + & + & + & + & + & + \\
\hline Elaidic acid & C $18: 1 \Delta 9$ (trans) & + & + & + & + & + & + & + & + \\
\hline Eicosanoic acid & C 20:1 $\Delta 11$ & & + & & + & + & + & & + \\
\hline Erucic acid & C 22:1 $\Delta 13$ & & & & & & & & \\
\hline
\end{tabular}

The polyunsaturated fatty acid (PUFA) composition is shown in Table 3. Omega-3 fatty acids ALA, ETA, and EPA were demonstrated to be present in all samples but not DHA. Results also reveal presence of several omega-6 fatty acids, among them are linoleic acid, an essential fatty acid that is incorporated in biological membranes; and arachidonic acid, the precursor of eicosanoids such as prostaglandins, leukotrienes, and thromboxanes.

Table 3:- Qualitative Profile of the Polyunsaturated Fatty Acid (PUFA) Composition

\begin{tabular}{|c|c|c|c|c|c|c|c|c|c|}
\hline \multirow[t]{2}{*}{ Common Name } & \multirow[t]{2}{*}{ Notation } & \multicolumn{2}{|c|}{ G.tenuistiptata } & \multicolumn{2}{|c|}{$\begin{array}{l}\text { C. racemosa } \\
\text { (Luzon) }\end{array}$} & \multicolumn{2}{|c|}{ H. nidulans } & \multicolumn{2}{|c|}{$\begin{array}{l}\text { C. racemosa } \\
\text { (Central } \\
\text { Philippines) }\end{array}$} \\
\hline & & June & Oct & June & Oct & June & Oct & June & Oct \\
\hline Linoleic acid & $\begin{array}{l}\text { C } 18: 2 \Delta 9,12 \\
(\square-6)\end{array}$ & + & + & + & + & + & + & + & + \\
\hline Linolenic acid (ALA) & $\begin{array}{l}\text { C } 18: 3 \Delta 9,12,15 \\
(\square-3)\end{array}$ & + & + & + & + & + & + & + & + \\
\hline Eicosadienoic acid & $\begin{array}{l}\text { C 20:2 } \quad \Delta \quad 11,14 \\
(\square-6)\end{array}$ & & + & + & + & + & + & + & + \\
\hline $\begin{array}{l}8,11,14 \text { eicosatrienoic } \\
\text { acid }\end{array}$ & $\begin{array}{l}\text { C 20:3 } \Delta 8,11,14 \\
(\square-6)\end{array}$ & + & + & + & + & + & + & + & + \\
\hline $\begin{array}{l}11,14,17 \\
\text { eicosatrienoic acid } \\
\text { (ETA) }\end{array}$ & $\begin{array}{l}\text { C 20:3 } \Delta 11,14,17 \\
(\square-3)\end{array}$ & + & + & + & + & + & + & + & + \\
\hline $\begin{array}{l}\text { Eicosatetraenoic acid } \\
\text { (arachidonic acid) }\end{array}$ & $\begin{array}{l}\text { C } 20: 4 \Delta 5,8,11,14 \\
(\square-6)\end{array}$ & + & + & + & + & + & + & + & + \\
\hline $\begin{array}{l}\text { Eicosapentaenoic acid } \\
\text { (EPA) }\end{array}$ & $\begin{array}{l}\text { C 20:5 } \Delta \quad 5, \quad 8, \\
11,14,17(\square-3)\end{array}$ & + & + & + & + & + & + & & + \\
\hline Docosadienoic acid & $\begin{array}{l}\text { C 22:2 } \Delta \quad 13,16 \\
(\square-6)\end{array}$ & & & + & & & & & \\
\hline $\begin{array}{l}\text { Docosahexaenoic acid } \\
\text { (DHA) }\end{array}$ & $\begin{array}{l}\text { C 22:6 } \Delta \quad 4, \quad 7, \\
10,13,16,19(\square-3)\end{array}$ & & & & & & & & \\
\hline
\end{tabular}

\section{Discussion:-}

Studies done by Gressler et al. (2010), Dawcynzki et al. (2007), Muralidhar et al. (2010), Ortiz et al. (2006), Ratanaarpon \& Chirapart (2006), and Sanchez-Machado et al. (2016), showed similar saturated fatty acid profile. Generally, data indicated the presence of polyunsaturated C12-C18 in most of the samples with variations when it comes to C20 or higher. In this study, saturated fatty acids C20 - C24 were detected in the green algae $C$. racemosa. However they were not observed in $G$. tenuistiptata and once only in $H$ nidulans, both classified as red algae. The presence of elaidic acid, a trans fatty acid, have also been shown in studies by J. Ortiz (2006). Oleic acid is a naturally occurring fatty acid. On the other hand elaidic, a trans fat, is implicated in the lowering of HDL and increasing LDL levels (Abbey and Nestel 1994). Erucic acid, a fatty acid found in rapeseed, mustard seed, and sunflower seed, was not detected. The presence of erucic diet is a health concern (Food and Standards Australia 
New Zealand 2003) since studies have shown that high amounts erucic acid in the diet of laboratory rats led to the development of myocardial lipidosis and heart lesions (Chariton et al. 1975). There were some differences in the lipid composition in the June and October collection and such is consistent with studies done by Khairy \& El-Shafay (2013) and Nelson et al. (2002).

Omega-3 fatty acids ALA, ETA, and EPA were found to be present in all the samples. However the presence of DHA was not detected. Dawczynski et al. (2007) and Sanchez-Machado et al. (2016) also demonstrated the presence of ALA and EPA. In the work of Dawczynski et al. (2007) docosapentaenoic acid (DPA) was observed instead of DHA in two out of the five samples. Gressler et al. (2010) demonstrated the presence of EPA in some of the samples but ALA, ETA, or DHA was not detected. On the other hand, J. Ortiz et al. (2006) and Ratana-arpon \& Chirapart (2006) detected ALA, EPA, and DHA in most of the seaweed samples, while Norziah and Ching (2000) detected EPA and DHA in G. changgi. Consistent with previous studies, omega-6 fatty acids were found to be also present. Linoleic acid is a component of phospholipids in biological membrane. On the other hand arachidonic acid is the precursor of eicosanoids like prostaglandins, leukotrienes, and thromboxanes. The US Dietary Guidelines in 2005 have recommended diets rich in MUFA and PUFA (US Dept of Health and Human Services, 2005). However with the potential health risks such as cardiovascular diseases associated with diets high in omega- 6 fatty acids, it has been recommended that food rich in PUFA must have relatively high omega-3 as compared to that of omega- 6 fatty acids (Intl. Food Information Council 2009; Simopoulus, A. 2010;).

\section{Conclusion:-}

This study has confirmed the presence of essential fatty acids including omega- 3 fatty acids in common seaweeds in the Philippines used for both human and animal consumption. These edible seaweeds, with its high nutritional value, can definitely be healthy alternative to the usual meal. However like other food products, possible risks of daily consumption should be evaluated.

\section{Acknowledgement:-}

The authors would like to express their utmost gratitude to the De La Salle University Research Coordination Office and De La Salle University Chemistry Department.

\section{References:-}

1. Abbey, M. and Nestel, P.J. (1994): Plasma cholesteryl ester transfer protein activity is increased when trans-elaidic acid is substituted for cis-oleic acid in the diet. Atherosclerosis, 106: 99-107.

2. Agree, J.J., Vaisanen, S., Hannien, O., Muller, A.D. \& Hornstra, G. (1997): Hemostatic factors and platelet aggregation after fish-enriched diet or fish oil or docosahexaenoic acid supplementation. Prostag. Leukot. Essent. Fatty Acids, 57: 419-421.

3. Benjama, O. \& Masniyom, P. (2012): Biochemical composition and physicochemical properties of two red seaweeds from the Pattani Bay in Southern Thailand. Sonklanakarin J. of Science and Technology, 34:223-230.

4. Bligh, E.G. and Dyer, W.J. (1959); A rapid method for total lipid extraction and purification. Canadian J. Biochem. Physiol, 37:911-917.

5. Bonaa, K. H., Bjerve, K. S., Straume, B., Gram, I. T. \& Thelle, D. (1990): Effect of eicosapentaenoic and docosahexaenoic acids on blood pressure in hypertension. A population-based intervention trial from the Tromso Study. N. Engl. J. Med., 322: 795-801.

6. Boonchum, W., Peerapornpisal, Y., Kanjanapothi, D., Pekkoh, J., Pumas, C., Jamjai, U., Amornlerdpison, D., Noiraksar, T., \& Panmuk (2011): Antioxidant activity of some seaweed from the Gulf of Thailand. Int. J. Agric. Biol., 13: 95-99.

7. Brownlee, I., Fairclough, A., Hall, A., \& Paxman, J. (2012): The potential health benefits of seaweed and seaweed extract. In: POMIN, Vitor H., (ed.) Seaweed: ecology, nutrient composition and medicinal uses. Marine Biology: Earth Sciences in the 21st Century, Hauppauge, New York, Nova Science Publishers, 119-136.

8. Chariton, K.M., Corner. A.H., Davey, K., Kramer, J.K.G., Mahadevan, S., and Dauer F.D (1975): Cardiac lesions in rats fed rape rapeseed oils. Can. J. Comp. Med., 39: 261-269.

9. Connor, W.E. (1994): Omega-3 fatty acids and heart disease. In: Kritchevsky, D., Caroll, K.K. (Eds.), Nutrition and Disease Update: Heart Disease. Am. Oil Chem. Soc., Champaign, Il.pp 7-42.

10. Dawczynski, C., Schurbert, R. \& Jahreis, R. (2007): Amino acids, fatty acids, and dietary fiber in edible seaweed products. Food Chemistry, 103: 891-899.

11. Fleurence, J. (1999): Seaweed proteins: biochemical, nutritional aspects and potential uses. Trends in Food Science and Technology, 10: 25-28. 
12. Food Standards Australia New Zealand (June 2003) Erucic acid in food: A toxicological review and risk Assessment Technical report series No. 21

13. Gressler, V., Yokoya, N., Fujioi, M., Colepicolo, P., Filho, J., Torres, R., \& Pinto, E. (2010): Lipid, fatty acid, protein, amino acid, and ash contents of four Brazilian red algae species. Food Chemistry, 120:585-590.

14. Harris, W.S. (1997): N-3 fatty acids and serum lipoproteins: human studies. Am. J. Clin. Nutr., 65: 16455-16545.

15. Horrocks, L.A. (1999): Health benefits of docosahexaenoic acid (DHA). Pharmacological Res, 40: 211-225.

16. International Food Information Council Foundation, Omega-6 Fatty Acid and Health Fact Sheet, 2009. http://www.foodinsight.org/Content/6/Omega-6_Fact_Sheet_6\%205\%2009\%20_2_.pdf.

17. Ismail, A. \& Hong, T. (2002): Antioxidant activity of selected commercial seaweeds. Mal. J. Nutrition. 8: 167-177.

18. Ismail, H.M. (2005): The role of omega-3 fatty acids in cardiac protection: on overview. Front Biosci, 10: 1079-1088.

19. Khairy, H. \& El-Shafay, S.M. (2013); Seasonal variations in the biochemical composition of some common seaweed species from the coast of Abu Qir Bay, Alexandria, Egypt. Oceanologia, 55: 435-452.

20. Kinsella, J. E., Lokesh, B., \& Stone, R. A., (1990): Dietary n-3 polyunsaturated fatty acids in amelioration of cardiovascular disease: possible mechanisms. Am. J. Clin. Nutr., 52, 1-28.

21. Kris-Etherton, P.M., Harris, W.S., \& Appel, L.J. (2003): Omega-3 fatty acids and cardiovascular disease: new recommendations from the American Heart Association. Arterioscler Thromb Vasc Biol., 23: 151-152.

22. Lou, H., Want, B. Yu C., Qu, Y, \& Su, C. (2010): Evaluation of antioxidant activities of five selected brown seaweeds from China. J. Medicinal Plant Research, 4: 2557-2565.

23. Matanjun, P., Mohamed, S., Mustapha, N. M., \& Muhammad, K. (2009): Nutrient content of tropical edible seaweeds, Eucheuma cotonii, Caulerpa lentillifera and Sargassum polycysum, J. Appl. Phycol., 21: 75-80.

24. Mohammadi, M. (2013): Nutritional composition of seaweeds from the Northern Persian Gulf. Iranian Journal of Fisheries Sciences, 12: 232-240.

25. Muralidhar, A. P., Syamala, K., Prakash, C.,Kalidas, C., \& Prasad Naik, R. (2010): Comparative Studies on Fatty Acid Composition of Three Marine Macroalgae Collected from Mandapan Region: South East Coast of India. World Applied Sciences Journal, 11: 958-965.

26. Nelson, M.M., Pheleger, C.F., \& Nichols, P.D. (2002): Seasonal lipid composition in macroalgae of northeastern Pacific Ocean. Botanica Marine, 45: 58-65.

27. Norziah, M. \& Ching, C. (2000): Nutritional composition of edible seaweed Gracilaria changgi. Food Chemistry, 68: 69-76.

28. Oomen, C.M., Freskens, E.J., Rasanen, L., Fidanza, F., Nissinem, A.M., Menotti, A., Kok, F.J. \& Kromhout, D. (2000): Fish consumption and coronary heart disease mortality in Finland, Italy and The Netherlands. Am. J. Epidemiol, 151:999-1006.

29. Ortiz, J., Romero, N., Robert, P., Araya, J., Lopez-Hernandez, J., Bozzo, C., Navarrete, E., Osorio, A., \& Rios, A. (2006): Dietary fiber, amino acid, fatty acid, and tocopherol contents of the edible seaweeds Ulva lactuca and Durvillaea antartica. Food Chemistry, 99: 98-104.

30. Polat, S., \& Ozogul, Y. (2013): Seasonal Proximate and Fatty Acid Variations of Seaweeds from the Northern Mediterranean Coast. Oceanologia, 55(2): 375-391.

31. Ratana-Arporn, P. \& Chirapart, A. (2006): Nutritional evaluation of tropical green seaweeds Caulerpa lentillifera and Ulva reticulata. Kasetsart J. (Nat. Sci.), 40: 75-83.

32. Sanchez-Machado D.I., Lopez-Cervantes, J., Lopez-Hernandez, J. \& Paseiro-Losada, P. (2004): Fatty acid, total lipid, proteins and ash content of processed edible seaweeds. Food Chemistry. 85: 439-444.

33. Schmidt, E.B. (1997): N-3 fatty acids and the risk of coronary heart disease. Danish Med. Bull., 44: 1-22.

34. Seenivasan. R, Rekha. M, Indu. H, \& Geetha. S., (2012): Antibacterial activity and phytochemical analysis of selected seaweeds from Mandapam Coast. Indian J of App Pharmaceutical Sci., 2:159-169.

35. Simopoulos, A. (2010). The omega-6/omega-3 fatty acid ratio: health implications. Nutrition-Santé, 17: $267-275$.

36. Shanab, S. (2007): Antioxidant and antibiotic activities of some seaweeds. Intl J Agr Biol., 9: 220-225.

37. Stone, N.J. (1996): Fish consumption, fish oil, lipids, and coronary heart disease. Circulation. 94:2337-2340.

38. Suresh, V., Kumar, N., Murugan, P., Palani, P., Rengasamy, R., \& Anbazhagan, C. (2012): Antioxidant properties of sequential extracts from brown seaweed, Sargassum plagiophyllum, C. Agardh. Asian Pacific Journal of Tropical Disease, S937-S939.

39. US Department of Health and Human Services, US Department of Agriculture, Dietary Guidelines for Americans, 2005. http://www.health.gov.dietary guidelines/dga2005/document/default.htm. 